\title{
Managerial Performance Based on Participation Budgetary, Islamic Work Motivation and Organizational Commitment
}

\author{
Faqih Nabhan \\ Faculty of Economic and Islamic business, State Islamic \\ Institut of Religion, Salatiga, Indonesia \\ faqihnabhan@iainsalatiga.ac.id
}

\author{
Diah Munfa'ati \\ Indonesian BMT Association Semarang Regency, \\ Salatiga, Indonesia \\ diahmunfa39ati@yahoo.co.id
}

\begin{abstract}
This study was started from the research gap on the influence of budgetary participation on managerial performance. This study aims to analyze managerial performance based on budgetary participation, Islamic work motivation, and organizational commitment, with structural equations (Structural Equation Model). The analysis results show that the budgetary participation variable is not able to encourage managerial performance and Islamic work motivation. Budgetary participation is proven to be able to increase organizational commitment and managerial performance. Thus, to improve managerial performance, budgetary participation must be able to increase organizational commitment first. Islamic work motivation is also proven to increase organizational commitment.

Keywords: budgetary participation, Islamic work motivation, organizational commitment, and managerial performance
\end{abstract}

\section{INTRODUCTION}

The effort to achieve managerial performance is needed in organizational studies. Maximum managerial performance is expected to be able to bring success to the company. Mayo [1] states that the main driver of successful performance is human resources with all their knowledge, ideas, and innovations. Human resources are the core of a company's values.

One of the factors that have a positive influence in terms of improving managerial performance is budget participation. According to Anthony and Govindarajan [2], participation in the budgeting process is a practical approach to increase managerial motivation. Budget participation provides an opportunity for human resources to be involved in budget preparation. Budget participation will improve the responsibility and performance of all employees at all levels.

There are differences in the results of research on the effect of budget participation on managerial performance. Employees' high participation in budget preparation activities will improve their managerial performance [3]. Mohd et.al., also stated that the higher the participation in budgeting, the higher the managerial performance [4]. Roman and nur, found that by participating in the preparation of budgets made in the company, managers can work together from the start, complement and support each other in achieving common goals to improve managerial performance [5]. Likewise,
Yusfaningrum, explains that when managers can increase participation in budgeting, employees feel involved from the start in preparing the activity budget, thereby improving managerial performance [6].

In contrast to the above findings, several other studies have found that participation in budgeting cannot improve managerial performance. Meidhayanti states that budget participation with low initiatives results in decreased managerial performance [7]. Furthermore, Revika, R., shows that budget participation reduces managerial performance [8]. This is because budget participation activities are carried out artificially. Cendra, D., also stated that budget participation reduces managerial performance because there are excessive intervention factors from budgeting leadership [9]. Likewise Ashari, B., found that budget participation has no effect on managerial performance, because there is someone who dominates in determining managerial performance [10]. Based on the consistency of the findings above, it is important to examine the effect of budget participation on managerial performance.

\section{LITERATURE REVIEW}

This study examines the role of motivation in budgetary participation by using goal setting theory. According to the viewpoint of goal setting theory, budget participation is difficult, but the budget objectives can be achieved and can be used to achieve better performance[11]. Goal-setting theory is a theory of motivation because humans have desires that become goals, and subsequent behavior is directed at these goals.

Budget participation can improve employee performance. However, the effect of budget participation on performance can be through organizational commitment first [12]. Organizations that encourage budgeting participation will get a high commitment from employees to promote employee performance achievement. Several literature reviews were conducted to develop the following hypotheses.

\section{A. Budget Participation on Managerial Performance}

Participation in budgeting is believed to be a managerial approach that can improve performance. Hasiniasi and Sholihin [13] state that high employee participation in budgeting activities will improve managerial performance [14]. Furthermore, Cahyadi and Handoko [15] and Yusfaningrum [6] found that with 
participation in budgeting, managers can work together, can complement and support each other in achieving common goals to improve managerial performance. However, several studies have found it different. Several other studies have found that participation in budgeting cannot improve managerial performance [7], [8], [9], [10]. Based on the findings above, the following hypothesis can be proposed:

H1: The higher the budget participation, the higher the managerial performance.

\section{B. Budget Participation on Islamic Work Motivation}

Motivation is the degree of encouragement that causes someone to want and try to do a task or job well, and a willingness to strive towards organizational goals [16]. Furthermore, motivation is a series of attitudes and values that influence individuals to achieve specific things in accordance with individual goals[17], [18]. In the perspective of budgeting, employees who have high motivation are more effective in achieving goals [19].

Work motivation in an Islamic perspective is a person's encouragement to do good to achieve goals and fulfill needs by making God the primary purpose [20]. Work motivation in Islam is not just an urge to pursue a hedonistic life or pursue wealth alone. The motivation for Islamic work is also not only to fulfill a living but also to fulfill the obligation to worship Allah SWT.

Cherrington [21], in his research, found that participation in budgeting has a positive and significant effect on motivation. Furthermore, Brownel and McInnes[17], Mia [18] say that there is a positive effect of budget participation on motivation. Based on the above analysis, the following hypothesis can be presented:

$\mathrm{H} 2$ : The higher the budget participation, the higher the Islamic work motivation

\section{Budget Participation on Organizational Commitment}

A budget prepared by involving all organization members will encourage organizational commitment [22]. Encourage increased commitment to the organization because organizational members feel that what is proposed in the budget is the result of their proposal. One crucial aspect of preparing a budget is organizational members' participation [23].

Dividing responsibility to organizational members in preparing a budget will increase the involvement of organizational members. The high participation of organizational members encourages disseminating information to all organization members [24]. Participation in budgeting can improve internal coordination and mutual support among organizational members. The involvement of organizational managerial processes in preparing budgets is one form of company appreciation to foster a sense of attachment and commitment to the organization [25]. From some of the research results above, the following hypothesis can be proposed:

H3: The higher the budget participation, the higher the organizational commitment.

\section{Islamic Work Motivation on Organizational Commitment}

Work motivation is a factor that can influence and shape organizational commitment [26]. Likewise, as stated by Mathiew and Jones [27], that work motivation can encourage increased organizational commitment. Employees who work motivated are happy and voluntarily committed to providing the best for the company. The better the work motivation in an organization will undoubtedly make the organizational commitment stronger. Therefore, the following hypothesis can be proposed:

H4: The higher the motivation to work in Islam, the higher the organizational commitment

\section{E. Organizational Commitment to Managerial Performance}

Organizational commitment is a bond between individuals in the organization so that the individual feels that he belongs to the organization where he works [28]. Then several researchers show that organizational commitment has a positive and significant effect on managerial performance [29], [30], [31]. It means that organizational commitment that is successfully built-in employees can encourage company managerial performance. Encouragement from within the individual to do something to support the success of the organization according to goals. Organizational commitment also raises an attitude of working to prioritize organizational interests rather than self-interests. Based on the above analysis, we could propose the following hypothesis:

H5: The higher the organizational commitment, the higher the managerial performance.

Based on the above literary and hypothesis analysis, the empirical research model was proposed as follows.

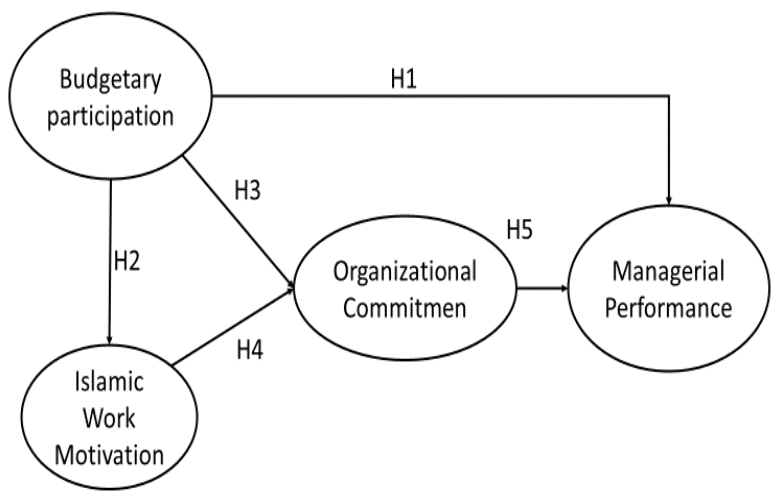

Fig. 1. Empirical model managerial performance

\section{RESEARCH METHOD}

This research is explanatory. The study population was all Baitul Maal Watamwil (BMT) Semarang and Salatiga City employees totaling 322 employees. The sample of this research was taken by using the purposive sampling method by distributing questionnaires to 109 employee respondents who work at Baitul Maal Wa Tamwil (BMT), members of the Indonesian BMT Association (PBMTI) Semarang Regency and Salatiga City. To test the hypothetical model, researchers used AMOS software.

\section{Measurement Assesment}

Four construct variables will be tested in the hypothesis. Each variable was measured using several indicators with a scale of 1 for the criterion strongly disagree to 10 strongly agree. The budget participation 
variable was measured by three indicators: involvement in the budget preparation process, accommodative attitude in revising the proposed budget, and contribution to providing advice [32]. Four variables measure the Islamic work motivation variable, namely working in worship, obeying the rules, working sincerely, and being enthusiastic at work [33].

Organizational commitment variables are measured by four indicators: pride in the organization, sense of belonging in the organization, trust, loyalty to the organization, and the need to remain [34]. Meanwhile, managerial performance is measured by five indicators, namely planning, investigation, coordination, evaluation, and supervision [35]. Each indicator is tested for validity and reliability, indicating that the value of the corrected ítem total correlation, which is above the $\mathrm{r}$ table, which is 0.196 , indicates a valid item. The results of the reliability test, the Cronbach alpha value for Budget Participation is 0.929, the Cronbach alpha value for Islamic Work Motivation is 0.871 , the Cronbach alpha value for Organizational Commitment is 0.883, and the Cronbach alpha value for Managerial Performance is 0.962 , which means that the Cronbach alpha value is more than 0.6 , meaning that the questionnaire in this research was reliable

\section{Data Analysis}

Four construct variables will be tested in the hypothesis. Each variable is measured using several indicators with a scale of 1 for the criterion strongly disagree, to 10 strongly agree. To validate the data, this study conducted a confirmatory factor analysis (CFA).

Based on the Confirmatory Factor analysis (CFA) test, several indicators were excluded from the model because they had high modification indices. The indicators used to measure budget participation are accommodative attitudes in revising the proposed budget and contributions in providing advice [32]. Islamic work motivation variable is measured by obeying the rules and enthusiasm for work [33]. Organizational commitment variables are measured by a sense of belonging in the organization and loyalty [34]. Meanwhile, managerial performance is measured by planning, coordinating, evaluating, and monitoring [35].

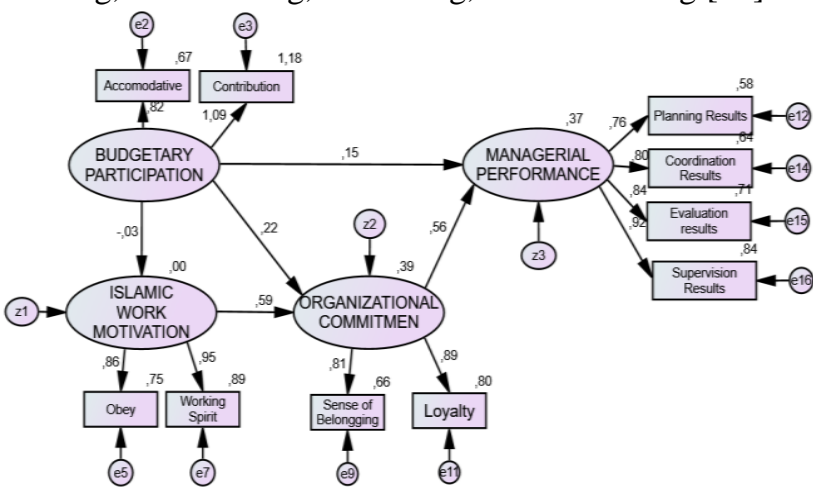

Fig.2. Empirical model, structural equation model (SEM)

The results of the structural equation model data processing with the AMOS application show that $\chi^{2}=35,959$, significance probability $=0.209, \mathrm{CFI}=0.992$, TLI $=0.987$, RMSEA $=0.043$ and CMIN / DF $=1.199$. Thus it can be concluded that the model is a good model acceptance because it has met the criteria for the goodness of fit indices. The structural model is presented in the following Figure 2.

\section{RESULT}

The results of the proposed hypothesis test presented in figure 3 and table 2. Table two found that of the five hypotheses, three hypotheses are accepted, and two are rejected. The following is the analysis and hypothesis test results.

TABLE I. STRUCTURAL ANALYSIS ON THE RESEARCH MODEL

\begin{tabular}{|llc|rrrl|}
\hline & & & \multicolumn{1}{|c|}{$\begin{array}{c}\text { Esti- } \\
\text { mate }\end{array}$} & C.R. & P & Result \\
\hline IWM & $\leftarrow$ & BP &,- 03 &,- 33 &, 742 & rejected \\
OC & $\leftarrow$ & BP &, 22 & 2,35 &, 019 & accepted \\
OC & $\leftarrow$ & IWM &, 59 & 5,72 & $* * *$ & accepted \\
MP & $\leftarrow$ & OC &, 56 & 5,02 & $* * *$ & accepted \\
MP & $\leftarrow$ & BP &, 15 & 1,75 &, 081 & rejected \\
\hline
\end{tabular}

Note: IWM= Islamic work motivation, $\mathrm{OC}=$ organizational commitment, $\mathrm{MP}=$ managerial performance, $\mathrm{BP}=$ budgetary participation

\section{A. Effect of Budget Participation on Managerial Performance}

The results of statistical testing show that hypothesis 1 the higher the budget participation, the higher the managerial performance is rejected. The estimated budgetary participation value of managerial performance is 0.152 (C.R. = 1.747). The results of this study are the same as some other research results. Revika, R. [36], shows that budget participation actually reduces managerial performance, this is because budget participation activities are carried out artificially. Cendra, D. [9], also stated that budget participation reduces managerial performance, because there are excessive intervention factors from the leadership in budgeting. Likewise Ashari, B. [10], found that budget participation has no effect on managerial performance, because there is someone who dominates in determining managerial performance. The results of this study are different from those of Yusfaningrum [6], Kunwaviyah [37] and Nor Yahya and Ahmad [38]. The results of this hypothesis test indicate that budgetary participation cannot directly improve managerial performance because budget participation can improve managerial performance and must be able to increase organizational commitment first. Even though budget participation has been carried out, but it is not able to increase employee commitment to the organization, its managerial performance cannot improve.

\section{B. The Effect of Budget Participation on Islamic Work Motivation}

The statistical testing results show that hypothesis 2, the higher the budget participation, the higher the Islamic working motivation is rejected. The value of estimate budgetary participation in Islamic work motivation is 0.029 (C.R. $=-0.329$ ). The budget participation variable 
cannot have a significant positive effect on Islamic work motivation, meaning that the better the participation in budgeting is not successful in increasing Islamic work motivation.

The findings of this hypothesis are different from those of other researchers [39], [19], and [40]. It's happening presumably because the increase in Islamic work motivation is more influenced by factors other than budget participation. Factors that can increase Islamic work motivation include an understanding of spiritual values, encouragement of life necessities, and job competition [41], [11] and [42].

\section{The Effect of Budget Participation on Organizational Commitment}

The statistical testing results show hypothesis 3, the higher the budget participation, the higher the organizational commitment is accepted. The estimated budgetary participation value for organizational commitment is $0.223(\mathrm{CR}=2.354)$. The results showed that budget participation was able to encourage organizational commitment, meaning that the better the participation in budgeting, the greater the organization. All members of the organization who are involved and collaborate in making decisions in the future will increase their commitment to work and achieve organizational goals. The results of this study support research Tahar \& Sofyani [23], Jermias \& Yigit [24] and De Baerdemaeker \& Bruggeman [25].

\section{The Effect of Islamic Work Motivation on}

\section{Organizational Commitment}

The statistical testing for hypothesis 4 shows an estimated value of $0.586($ C.R. $=5.720)$. This means that the hypothesis is that the higher the Islamic work motivation, the higher the organizational commitment is accepted. The results showed that Islamic work motivation has a significant positive effect on organizational commitment, meaning that the better Islamic work motivation, the better organizational commitment will be. The better Islamic work motivation in an organization will certainly make the organizational commitment stronger. The results of this study support research Guerrero, Lapalme, \& Séguin [43], Orpen [44], and Sinclair [45].

\section{E. The Effect of Organizational Commitment on}

\section{Managerial Performance}

The statistical testing results showed the standard value estimated for the influence of the organizational commitment variable on managerial performance of 0.555 (C.R. = 5.022). This means that hypothesis 5, the higher the organizational commitment, the higher the managerial commitment is received. High organizational commitment can encourage higher managerial performance. This result is in line with the research results by Oktavia [46] and Wulandari [47], which show that organizational commitment has a positive and significant effect on managerial performance.

Based on the value of the indirect effect and the total effect, the influence of budgetary participation on managerial performance indirect effect $=0.114$ and the total effect $=0.266$. While the influence of Islamic work motivation on managerial performance indirect effect = 0.325 and the total effect $=325$. This means that in improving managerial performance, Islamic work motivation has a more significant influence than budget participation. In other words, to improve an organization's managerial performance, it is better to pay attention to Islamic work motivation, which can increase organizational commitment and further improve managerial performance.

\section{CONCLUSIONS}

This study discusses the effect of budget participation on company managerial performance. Organizational commitment and Islamic work motivation are expected to bridge the influence of budget participation on managerial performance. Based on the hypothesis testing, here are some things that were found in this study.

First, budget participation is not able to directly improve managerial performance. This finding is in line with the results of Revika, R. [8], Cendra, D. [9], and Ashari, B. [10]. This is because to improve managerial performance, budget participation must be able to increase organizational commitment first. If participation in budgeting can increase organizational commitment, then managerial performance will increase.

Second, budget participation is not able to increase Islamic work motivation. This finding is different from the results of Pradana [39], Riyadi, S [19], and Revano [40]. This is presumably because the increase in Islamic work motivation is more influenced by factors other than budget participation. Factors that can increase Islamic work motivation include the understanding of spiritual values, encouragement of life necessities, and job competition Jayaweera [41], Latham \& Pinder [48], and Dysvik \& Kuvaas [42].

Third, budget participation is proven to be able to increase organizational commitment. The higher the budget participation, the higher the organizational commitment. The findings of this study are in line with the results Tahar \& Sofyani [23], Jermias \& Yigit [24], and De Baerdemaeker \& Bruggeman [25].

Fourth, Islamic work motivation can increase organizational commitment. Organizational commitment is not only driven by budget participation but also Islamic work motivation. Islamic work motivation, in this case, obey and working spirit, succeeded in increasing employee commitment to the organization. This is in line with the findings of several researchers Sinclair [45], Orpen [44], and Guerrero et. al. [43].

Fifth, organizational commitment is able to encourage increased managerial performance. The results of this fifth hypothesis test answer the research gap presented above, that there is controversy over the results of research on the effect of budget participation on managerial performance. Budget participation can improve managerial performance by first increasing the organizational commitment. This is in line with the findings of Oktavia [46], Wulandari [47], and Michelet et.al., [49] dan Bioulac, Guehl, \& Burbaud [49].

Sixth, Islamic work motivation has a higher effect than budgetary participation in increasing managerial performance. To improve managerial performance, 
organizations should pay attention to Islamic work motivation to increase organizational commitment and improve managerial performance.

Some of the limitations of the study are in determining indicators. From the results of the Exploratory factor analysis test, it was decided to delete several indicators. This shows that the proposed indicators are not valid. Therefore, future research should reformulate each variable's indicators, especially from the variable budget participation, Islamic work motivation, and organizational commitment.

\section{REFERENCES}

[1] A. Mayo, "The role of employee development in the growth of intellectual capital," Personnel Review, 2000.

[2] R. N. Anthony and V. Govindarajan, "Management control systems," 2007.

[3] S. Zainuddin and R. C. Isa, "The role of organizational fairness and motivation in the relationship between budget participation and managerial performance: A conceptual paper," Australian Journal of Basic and Applied Sciences, vol. 5, no. 12, pp. 641-648, 2011.

[4] I. H. Mohd Noor and R. Othman, "Budgetary participation: How it affects performance and commitment," Accountancy Business and the Public Interest, 2012.

[5] M. T. N. Rokhman, "Improving Managerial Performance through Participation Role of Budget Preparation: a Theoretical and Empirical Overview," Journal of Economics and Finance, vol. 8, no. 1, pp. 39-43, 2017.

[6] K. Yusfaningrum, "Analisis Pengaruh Partisipasi Anggaran Terhadap Kinerja Manajerial Melalui Komitmen Tujuan Anggaran Dan Job Relevant Informahon (Jri) Sebagai Variabel Intervening (Penelitian Terhadap Perusahaan Manufaktur Di Indonesia)," Program Pascasarjana Universitas Diponegoro, 2005.

[7] P. M. Yanti and K. A. Suardana, "Pengaruh partisipasi anggaran terhadap kinerja manajerial dengan self efficacy, desentralisasi, dan budaya organisasi sebagai variabel pemoderasi," E-Jurnal Akuntansi, vol. 11, no. 1, pp. 155-170, 2015.

[8] E. Ilham, Z. Zulbahridar, and R. Revika, "Pengaruh Kualitas Sumber Daya Manusia, Komitmen Organisasi, Komunikasi Organisasi, dan Partisipasi Anggaran terhadap Kinerja Satuan Kerja Perangkat Daerah (Skpd) di Kota Payakumbuh," Riau University, 2015.

[9] D. C. Bhakti, E. Pituringsih, and E. Widiastuty, "Pengaruh Partisipasi Penyusunan Anggaran, Kejelasan Sasaran Anggaran, dan Profesionalisme Sumber Daya Manusia terhadap Kinerja Manajerial," Assets: Jurnal Ekonomi, Manajemen dan Akuntansi, vol. 5, no. 1, pp. 29-43, 2015.

[10] B. Ashari, "Pengaruh Partisipasi Penyusunan Anggaran Terhadap Kinerja Manajerial Dengan Budaya Organisasi Dan Struktur Organisasi Sebagai Variabel Moderating (Studi Empiris pada SKPD di Kabupaten Agam)," Jurnal Akuntansi, vol. 1, no. 3, 2013.

[11] E. A. Locke and G. P. Latham, A theory of goal setting \& task performance. Prentice-Hall, Inc, 1990.

[12] H. Nouri and R. J. Parker, "The relationship between budget participation and job performance: the roles of budget adequacy and organizational commitment," Accounting, Organizations and society, vol. 23, no. 5-6, pp. 467-483, 1998.

[13] R. Hasniasari and M. Sholihin, "Analisis Hubungan Penganggaran Partisipatif dan Kinerja: Pengujian Efek Mediasi Keadilan Persepsian dan Komitmen pada Lembaga Hukum Sektor Publik di Indonesia," Jurnal Akuntansi dan Keuangan, vol. 16, no. 1, pp. 2332,2014

[14] R. A. Bumulo, L. Kalangi, and J. Warongan, "Pengaruh Partisipasi Penyusunan Anggaran terhadap Kinerja Manajerial dengan Motivasi, Komitmen Organisasi, dan Job relevant information (JRI) sebagai Variabel Moderating pada Perguruan Tinggi Swasta di Provinsi Gorontalo," JURNAL RISET AKUNTANSI DAN AUDITING" GOODWILL", vol. 9, no. 1, 2019.

[15] R. S. Cahyadi and J. Handoko, "Pengaruh Komitmen Organisasi, Gaya Kepemimpinan, dan Ketidakpastian Lingkungan terhadap
Hubungan Partisipasi Anggaran dengan Kinerja Manajerial," Jurnal Akuntansi Kontemporer, vol. 2, no. 2, 2010.

[16] M. S. Hasibuan and H. M. S. Hasibuan, Manajemen sumber daya manusia. Bumi Aksara, 2016.

[17] P. Brownell and J. M. McInnes, "Budgetary participation, motivation and managerial performance," 1983.

[18] L. Mia, "Managerial attitude, motivation and the effectiveness of budget participation," Accounting, Organizations and Society, vol. 13, no. 5, pp. 465-475, 1988 .

[19] S. Riyadi, "Pengaruh desentralisasi, motivasi, dan partisipasi anggaran terhadap kinerja manajerial pada perusahaan manufaktur yang terdaftar di Bursa Efek Jakarta," Jurnal Ekonomi dan Bisnis Airlangga (JEBA), vol. 17, no. 2, 2007.

[20] A. Rahman, "An Islamic perspective on organizational motivation," American Journal of Islamic Social Sciences, vol. 12, no. 2, pp. 115-124, 1995.

[21] J. A. Fossum, "The effects of positively and negatively contingen rewards and individual differences on performance, satisfaction, and expectations," Academy of Management Journal, vol. 22, no. 3, pp. 577-589, 1979.

[22] B. JATMIKO, T. LARAS, and A. ROHMAWATI, "Budgetary Participation, Organizational Commitment, and Performance of Local Government Apparatuses," The Journal of Asian Finance, Economics, and Business, vol. 7, no. 7, pp. 379-390, 2020.

[23] A. Tahar and H. Sofyani, "Budgetary Participation, Compensation, and Performance of Local Working Unit: The Intervening Role of Organizational Commitment," Journal of Accounting and Investment, vol. 21, no. 1, pp. 145-161, 2020.

[24] J. Jermias and F. Yigit, "Budgetary participation in Turkey: The effects of information asymmetry, goal commitment, and role ambiguity on job satisfaction and performance," Journal of International Accounting Research, vol. 12, no. 1, pp. 29-54, 2013.

[25] J. De Baerdemaeker and W. Bruggeman, "The impact of participation in strategic planning on managers' creation of budgetary slack: The mediating role of autonomous motivation and affective organisational commitment," Management Accounting Research, vol. 29, pp. 1-12, 2015.

[26] A. Can and Y. Yasri, "Pengaruh Motivasi Kerja, Kepuasan Kerja Dan Komitmen Organisasi Terhadap Kinerja Karyawan Pada Bank Nagari," Jurnal Riset Manajemen Bisnis dan Publik, vol. 4, no. 1, 2016.

[27] J. E. Mathieu and J. L. Farr, "Further evidence for the discriminant validity of measures of organizational commitment, job involvement, and job satisfaction," Journal of applied psychology, vol. 76 , no. 1 , p. 127,1991

[28] R. S. Supriyono, "Pengaruh variabel intervening kecukupan anggaran dan komitmen organisasi terhadap hubungan antara partisipasi penganggaran dan kinerja manajer di Indonesia," Journal of Indonesian Economy and Business, vol. 19, no. 3, 2004.

[29] J. J. Quirin, D. P. Donnelly, and D. O Bryan, "Consequences of participative budgeting: The roles of budget-based compensation, organizational commitment, and managerial performance," Advances in Management Accounting, vol. 9, pp. 127-144, 2000

[30] K. O. Ogiedu and J. Odia, "Relationship between budget participation, budget procedural fairness, organizational commitment and managerial performance," Review of Public Administration and Management, vol. 2, no. 3, pp. 234-250, 2013.

[31] J. D. Manafe and T. Setyorini, "The impact of organizationa commitment as mediator and moderator relationship between budgeting participation on managerial performance," The International Journal of Social Sciences World (TIJOSSW), vol. 1, no. 01, pp. 11-20, 2019.

[32] K. Milani, "The relationship of participation in budget-setting to industrial supervisor performance and attitudes: a field study," The accounting review, vol. 50, no. 2, pp. 274-284, 1975.

[33] A. Saleh, "Muwafik. Bekerja dengan Hati Nurani," ed: Jakarta: PT. Erlangga, 2009.

[34] J. P. Meyer, N. J. Allen, and C. A. Smith, "Commitment to organizations and occupations: Extension and test of a threecomponent conceptualization," Journal of applied psychology, vol. 78, no. 4, p. 538, 1993

[35] T. A. Mahoney, Development of managerial performance: A research approach. South-western Publishing Company, 1963.

[36] T. Erawati, "Pengaruh Pemanfaatan Teknologi Informasi, Pengendalian Internal dan Komitmen Organisasi Terhadap Kinerja 
Organisasi (Studi Kasus Satuan Kerja Perangkat Daerah Kabupaten Gunungkidul)," Jurnal Akuntansi Pajak Dewantara, vol. 1, no. 1, pp. 93-102, 2019.

[37] N. Kunwaviyah, "Pengaruh Partisipasi Anggaran Terhadap Kinerja Manajerial Melalui Komitmen Organisasi dan Persepsi Inovasi sebagai Variabel Intervening," Universitas Diponegoro, 2010.

[38] M. N. Yahya, N. N. N. Ahmad, and A. H. Fatima, "Budgetary participation and performance: some Malaysian evidence," International Journal of Public Sector Management, 2008.

[39] I. M. Pradana, "Pengaruh Motivasi dan Pelimpahan Wewenang sebagai Variabel Moderating Terhadap Hubungan Antara Partisipasi Penyusunan Anggaran dan Kinerja Manajerial (Studi Empiris pada Hotel Bintang Di Bali)," Tesis-S2. Universitas Diponegoro. Semarang, 2002.

[40] R. Ramadanil, "Pengaruh Partisipasi Penyusunan Anggaran Dan Motivasi Kerja Terhadap Kinerja Satuan Kerja Perangkat Daerah (Studi Empiris Pada SKPD Kab. Tanah Datar)," Jurnal Akuntansi, vol. 1, no. 3, 2013.

[41] T. Jayaweera, "Impact of work environmental factors on job performance, mediating role of work motivation: A study of hotel sector in England," International journal of business and management, vol. 10, no. 3, p. 271, 2015.

[42] A. Dysvik and B. Kuvaas, "The relationship between perceived training opportunities, work motivation and employee outcomes," International Journal of Training and Development, vol. 12, no. 3, pp. 138-157, 2008.

[43] S. Guerrero, M.-E. Lapalme, and M. Séguin, "Board chair authentic leadership and nonexecutives' motivation and commitment," Journal of Leadership \& Organizational Studies, vol. 22, no. 1, pp. 88-101, 2015.

[44] C. Orpen, "The effects of formal mentoring on employee work motivation, organizational commitment and job performance," The Learning Organization, 1997.

[45] C. Sinclair, "Initial and changing student teacher motivation and commitment to teaching," Asia - Pacific Journal of Teacher Education, vol. 36, no. 2, pp. 79-104, 2008.

[46] D. Octavia, "Pengaruh Partisipasi Anggaran, Gaya Kepemimpinan, Dan Komitmen Organisasi Terhadap Kinerja Manajerial Pada PT Pos Indonesia (Persero) Medan," 2009.

[47] D. A. Wulandari, "Pengaruh Proses Rekrutmen Karyawan Terhadap Kinerja Karyawan Melalui Komitmen Organisasi Pada PT. Indonesia Dwi Sembilan (IDS) Cabang Kabupaten Jember," Tidak Dipublikasikan. Skripsi. Jember: Universitas Jember, 2014.

[48] G. P. Latham and C. C. Pinder, "Work motivation theory and research at the dawn of the twenty-first century," Аппи. Rev. Psychol., vol. 56, pp. 485-516, 2005.

[49] T. Michelet, B. Bioulac, D. Guehl, and P. Burbaud, "Impact of commitment on performance evaluation in the rostral cingulate motor area," Journal of Neuroscience, vol. 27, no. 28, pp. 74827489, 2007. 